\title{
Analysis of Potential Creative Industry for People with Disabilities in Special Region of (D. I) Yogyakarta
}

\author{
${ }^{1}$ SAHABUDIN SIDIQ, ${ }^{2}$ HERI SUDARSONO, ${ }^{3}$ SARASTRI MUMPUNI RUCHBA \\ ${ }^{4}$ ANDIKA RIDHA AYU PERDANA \\ 1,2,3,4 Program Studi Ilmu Ekonomi, Universitas Islam Indonesia \\ email: ${ }^{1}$ sahabuddin@uii.ac.id; ${ }^{2}$ heri.sudarsono@uii.ac.id; ${ }^{3}$ sarastri@uii.ac.id; ${ }^{4}$ andika.ayu@uii.ac.id;
}

\begin{abstract}
This study aims to determine the potential of creative industries for people with disabilities in Yogyakarta. By gathering data from small and medium industries (IKM), creative industries, documents, interviews, and using qualitative description approach as a method of analysis, this research finds at least five important results. Firstly, people with deaf-mute condition and physical disability can work on all types of creative industries, but mental disability and mental-physical disability can only work on certain types of industry. Secondly, craft industry is the most widely sector for people with disabilities to earn more income. Thirdly, Bantul and Gunungkidul provide many jobs opportunities in creative industries compared to other districts. Fourthly, the potential of disabled people to work in creative industries decreases from 2014 to 2015 except for Yogyakarta City. The last one, job opportunity for people with disabilities may potentially be increased by expanding the type of business in Yogyakarta.
\end{abstract}

Keywords: Creative Industry, People with Disabilities, Yogyakarta

\section{Introduction}

According to the Law of the Republic of Indonesia No. 8 of 2016 concerning People with Disabilities, it states that the disabled is part of Indonesian society who has equal status, rights, obligations, and roles with other Indonesians in all aspects of life and livelihood. They also deserve to get intended rights such as to obtain education, employment and economic development, to use public facilities, to communicate and obtain information, to have legal protection, political role, social security and health, and cultural development (Dewi, 2015; Rizano, 2014)

However, the disabled have not fully obtained the above rights due to some problems. People might think they have a lack of or even zero capability to work. Such thought leads most people to hardly accept the disabled to work with them (Santoso and Apsari, 2017; Rosdianti, 2017; Booth, 2003). Moreover, the government has not fully able to perform their duties to be a bridge for the disabled and assist them in obtaining their rights in order to be equal with others in community. (Heera and Devi. 2016; Kaye, et al. 2011 ). Therefore, issue of discrimination in various fields such as education, economy, social, culture, and political, is very much inherent to the disabled (Salim, 2015; Rahayu et al, 2013).

Actually, Government has also Decree of Minister No. 205/Men/1999 regarding Job Training and Placement for the Disabled Workers. This decree can be an opportunity for the disabled since one point in the decree states that there have to be one disabled worker for every 100 workers in a company. However, this policy seems difficult to be implemented as evidenced by most jobs which require candidates with good physical and mental health (Rizano, 2014). This requirement becomes legitimacy for private institutions to refuse the disabled. As a consequence, most of the disabled prefer to work in informal sector which has low capital and labor, low capacity of production, limited distribution, and having no-perfect-health requirement. The very popular informal sector

Received: October 30, 2017, Revision: February 12, 2018, Accepted: June 04, 2018

Print ISSN: 0215-8175; Online ISSN: 2303-2499. DOI: http://dx.doi.org/10.29313/mimbar.v34i1.3165.102-111

Accredited B based on the decree No.040/P/2014, valid on February, 18, 2014 until February, 18, 2019. Indexed by DOAJ, Sinta, IPI 
for the disabled is service, such as massage and tailor. These services are less likely to improve and increase their welfare (Harahap and Bustanuddin. 2015; Maharani, 2014, Latuconsina, 2014).

According to Demography Department in D.I (special region) of Yogyakarta (DIY), there are six types of people with disabilities: people with deaf-mute condition, visual impairment, physical impairment, mental impairment, both physical-mental impairment, and others. The Department also shows that DIY has 9.223 people with disabilities in 2016. Based on this amount, there are 3.312 or around $35.9 \%$ live in Gunungkidul and 1.679 (18.2\%) live in Sleman, In Sleman, most of disabled people live there are having physical impairment. The following figure shows the percentage of the disabled in every district based on the types. The first rank is people with physical impairment $(39 \%)$, followed respectively by mental impairment $(20.1 \%)$, deaf-mute condition $(14,3 \%)$, others $(10,8 \%)$, visual impairment $(9,7 \%)$, and physical-mental impairment $(9,7 \%)$,

The government's plan in developing creative industries in every district is actually assist the disabled to be actively involved in local development. Unfortunately, the real condition shows the opposite. The disabled has limitation to access certain facilities such as education, training, as well as fund to expand the business. These facilities would increase the potential of the disabled to be more competitive in labor market. (Surwati, 2014; Masduqi, 2010)

The process of establishment, management, development, and assistance are needed to give contribution for the disabled. The process also needs some great contribution from various kinds of society supported by the government, nongovernment organization, financial institution, businessman, and education institution through a systemic plan. (Aji, 2017; Dewi, 2015; Latuconsina, 2014) These contributions, hopefully, can create more creative industry models for people with disabilities. (Nurjanah, 2013; Hwa. 2012.)

Act No 41997 defines the term of disability as every single person that having physical and or mental impairment which bother her/himself to do certain activities. Most of the impairments are caused by poverty condition or vice versa. Poverty leads to a bad condition such as malnutrition, poor health sanitation, and cannot easily access proper health facilities. Conversely, the disabled can be trapped into poverty due to some barriers such as access for education, work, social activities, and other aspects of life (Lestari. et al, 2017; Nasution. et al, 2014). In addition, the condition is worsened by ignoring the disabled in development process, whereas they should be seen as part of population and development (Kang, 2013; Gustafasson, et al. 2013). In such situation, welfare becomes very difficult to be achieved (Indrajaya, 2017).

Efforts to improve the welfare of the disabled have been undertaken by the government through the opening of accesses for creative industry. The creative industry's character that is more adaptive to all basic human potentials will be capable of prospering the disabled. (Mik-Meyer, 2016; Huang and Chen, 2015; Naraine and Lindsay, 2011). Creative economy covers a transition

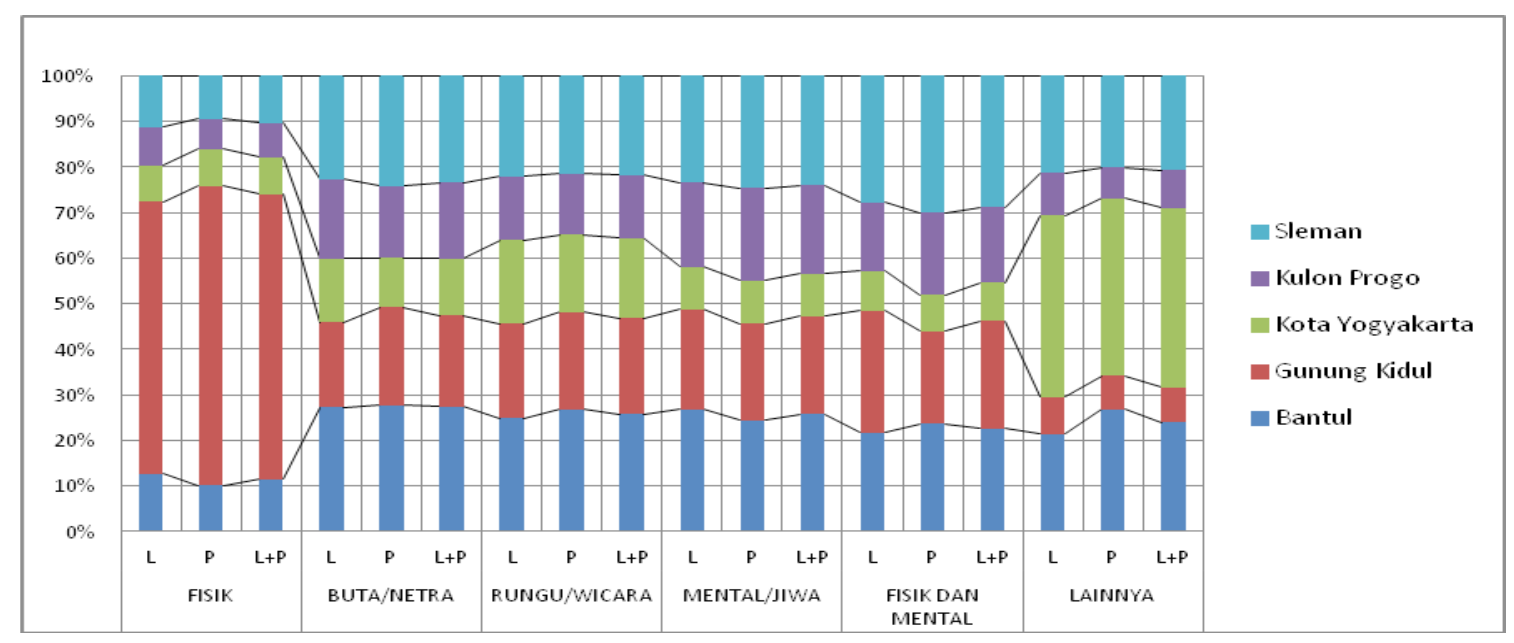

Source: Demography Department DIY, 2017

Figure 1. The Population of People with Disabilities in DIY 2016 
from ideas and expressions of creativity into a product that has commercial value and intellectual property, including design, architecture, fashion, advertising, printing and publishing, television and radio, culinary, art and craft, film, video, animation, music, photography, and tools (Lestari. 2013).

\section{Research Method}

This study is a descriptive qualitative research where the process and meaning of the research will be more highlighted. The first step is to create a matrix of the disabled who work in 15 different creative industries. The second step is to identify the types of creative industries that are categorized as small and medium industries (IKM). The third step, weighting based on the number of types of the disabled working in the creative industry and IKM. The fourth step is to find out the proportion of the disabled in each type of IKM in every district in Yogyakarta. The fifth step is to find the number of the disabled who work in each type of IKM, and the last step is to find the potential of the disabled to work in the IKM.

This study uses primary data obtained from interview and secondary data sourced from documents of the residence, industries, and labor agencies. (Hendriasyah, 2013). Interviews were conducted with 6 respondents consisting of NGO CIQAL chairman, DIY public works agency, DIY industry office, banking, and representatives of the disabled and disable entrepreneur. Then, to explore the information, 6 respondents met in Focus Group Discussion (FGD). (Moeliono, 2012) FGDs were conducted to compile disabled people who worked in 15 different creative industries and identify the criteria and number of IKM, disable proportions, and potential work in each IKM.

Domain analysis aims to answer complex problem in order to get a whole picture of research object. Moreover, this analysis is conducted as the way to know all the details about the research study. (Moleong, 2000) The analysis is then utilized to reveal the relationship between the relevant factor of creative industry and the disable people. Furthermore, content analysis is the last analysis that aims to find the classification of the criteria and predict future circumstances. Mathematical analysis will be used to measure the potential of the disabled working in the creative industries.

\section{Profile of Small and Medium Indus- tries (IKM) in DIY}

IKM plays a great role in the economics of society. Some functions of IKM will be described below such as IKM's great contribution in producing some unique goods and services, and IKM's role in reducing number of unemployment in one region including the disable people. So far, IKM is seen as the best industry for the disabled since it suits their special and unique needs. According to Bureau of Statistic Center in DIY, IKM is defined as manufacture industry which has less than 20 labor forces for small industry and less than 100 labors for medium ones.

Five main industries developing greatly in DIY as follows: food, fashion and leather, chemical and construction material, steel and electronics, and craft. Table 1 indicates the massive opportunities of IKM in DIY specifically in each region. It is shown that among all those five main industries, food sector has the biggest business unit followed respectively by craft sector, chemical and construction material, fashion and leather, and steel and electronics sector. The table also illustrates that the food sector has rapidly increased from 2014 to 2015 on both business unit side and labor force.

The above table depicts information that Kulonprogo holds the biggest number for region having business unit and labor force on food industry followed by the city of Yogyakarta, Bantul, Sleman, and Gunungkidul. Craft industry is then noted as the second biggest industry after food industry. Bantul is stated to have the business unit and labor force amount on the biggest industry followed by Kulonprogo, Sleman, Gunungkidul, and city of Yogyakarta.

By the perspective of opportunity on chemical and construction materials, Bantul has the biggest number of business unit and labor force followed by Gunung Kidul, Sleman, Kulon Progo, and Yogyakarta. Besides, seen from the opportunity to work on fashion and leather industry, Sleman takes place as the biggest number of business unit and labor force followed by Bantul, Yogyakarta, Sleman and Gunung Kidul. The illustration of the table gives point of view from the industry of steel and electronics which states that Sleman mainly dominates the number of business units and labor force then respectively followed by Gunungkidul, Bantul, Kulonprogo, and Yogyakarta City. 
Table 1

Detail of Small Medium Enterprise (IKM) in DIY

\begin{tabular}{|c|c|c|c|c|c|c|c|c|}
\hline \multirow[t]{2}{*}{ No } & \multirow[t]{2}{*}{ Region } & \multirow[t]{2}{*}{ Business types } & \multicolumn{2}{|c|}{$\begin{array}{c}\text { Business } \\
\text { Unit }\end{array}$} & \multicolumn{2}{|c|}{ Labor Force } & \multicolumn{2}{|c|}{ Production Value } \\
\hline & & & 2014 & 2015 & 2014 & 2015 & 2014 & 2015 \\
\hline \multirow{5}{*}{1} & \multirow{5}{*}{ Bantul } & Food & 8.112 & 8.290 & 26.888 & 27.480 & 302.618 .665 & 311.697 .225 \\
\hline & & $\begin{array}{l}\text { Fashion and } \\
\text { Leather }\end{array}$ & 836 & 854 & 6.639 & 6.719 & 197.801 .503 & 202.153 .136 \\
\hline & & $\begin{array}{l}\text { Chemical and } \\
\text { construction } \\
\text { material } \\
\end{array}$ & 3.005 & 3.101 & 28.190 & 28.246 & 288.489 .061 & 299.925 .772 \\
\hline & & $\begin{array}{l}\text { Steel and } \\
\text { Electronics }\end{array}$ & 1.003 & 1.035 & 2.894 & 2.900 & 36.750 .133 & 38.293 .639 \\
\hline & & Craft & 6.855 & 7.143 & 23.842 & 24.772 & 91.185 .325 & 94.103 .225 \\
\hline \multicolumn{3}{|c|}{ Total } & 19.811 & 20.423 & 88.453 & 90.117 & 916.844 .687 & 946.172 .997 \\
\hline \multirow{5}{*}{2} & \multirow{5}{*}{$\begin{array}{l}\text { Gunung } \\
\text { Kidul }\end{array}$} & Food & 9.064 & 9.263 & 34.117 & 34.868 & 75.718 .680 & 68.623 .420 \\
\hline & & \begin{tabular}{|l}
$\begin{array}{l}\text { Fashion and } \\
\text { Leather }\end{array}$ \\
\end{tabular} & 1.009 & 1.031 & 2.283 & 2.310 & 31.758 .138 & 22.850 .017 \\
\hline & & $\begin{array}{l}\text { Chemical and } \\
\text { construction } \\
\text { material } \\
\end{array}$ & 5.630 & 5.810 & 20.889 & 10.931 & 28.709 .211 & 29.411 .993 \\
\hline & & \begin{tabular}{|l|} 
Steel and \\
Electronics \\
\end{tabular} & 884 & 912 & 3.737 & 3.744 & 14.869 .585 & 13.879 .008 \\
\hline & & Craft & 4.660 & 4.856 & 13.971 & 14.362 & 44.785 .171 & 39.745 .592 \\
\hline \multicolumn{3}{|c|}{ Total } & 21.247 & 21.872 & 74.997 & 66.215 & 195.840 .785 & 174.510 .030 \\
\hline \multirow{5}{*}{3} & \multirow{5}{*}{ Yogyakarta } & Food & 1.976 & 2.019 & 7.070 & 7.228 & 131.293 .821 & 135.232 .636 \\
\hline & & \begin{tabular}{|l} 
Fashion and \\
Leather
\end{tabular} & 887 & 907 & 5.447 & 5.512 & 88.450 .066 & 90.395 .967 \\
\hline & & $\begin{array}{l}\text { Chemical and } \\
\text { construction } \\
\text { material } \\
\end{array}$ & 649 & 670 & 5.960 & 5.972 & 102.571 .691 & 105.824 .665 \\
\hline & & $\begin{array}{l}\text { Steel and } \\
\text { electronics }\end{array}$ & 672 & 694 & 2.103 & 2.107 & 53.677 .441 & 55.931 .894 \\
\hline & & Craft & 949 & 989 & 6.443 & 6.624 & 81.772 .611 & 84.389 .335 \\
\hline \multicolumn{3}{|c|}{ Total } & 5.133 & 5.279 & 27.023 & 27.443 & 457.765 .630 & 471.774 .497 \\
\hline \multirow{5}{*}{4} & \multirow{5}{*}{$\begin{array}{l}\text { Kulon } \\
\text { Progo }\end{array}$} & Food & 13.289 & 13.583 & 37.137 & 37.953 & 223.562 .691 & 230.269 .572 \\
\hline & & \begin{tabular}{|l} 
Fashion and \\
Leather
\end{tabular} & 976 & 998 & 3.336 & 3.377 & 22.991 .864 & 23.497 .685 \\
\hline & & \begin{tabular}{|l|} 
Chemical and \\
construction \\
material \\
\end{tabular} & 1.046 & 1.080 & 3.778 & 3.786 & 44.244 .943 & 46.775 .870 \\
\hline & & $\begin{array}{l}\text { Steel and } \\
\text { electronics }\end{array}$ & 853 & 881 & 2.470 & 2.476 & 15.717 .691 & 16.377 .832 \\
\hline & & Craft & 6.379 & 6.646 & 18,972 & 19.522 & 78.228 .186 & 80.731 .518 \\
\hline \multicolumn{3}{|c|}{ Total } & 22.543 & 23.188 & 46.740 & 67.114 & 384.745 .375 & 397.652 .477 \\
\hline \multirow{5}{*}{5} & \multirow{5}{*}{ Sleman } & Food & 6.128 & 6.263 & 19.456 & 19.884 & 380.640 .866 & 392.060 .092 \\
\hline & & \begin{tabular}{|l|} 
Fashion and \\
leather
\end{tabular} & 1.743 & 1.781 & 9.182 & 9.292 & 231.173 .224 & 236.259 .035 \\
\hline & & $\begin{array}{l}\text { Chemical and } \\
\text { construction } \\
\text { material } \\
\end{array}$ & 3.064 & 3.162 & 16.640 & 16.673 & 697.620 .581 & 612.662 .345 \\
\hline & & $\begin{array}{l}\text { Steel and } \\
\text { electronics }\end{array}$ & 1.826 & 1.886 & 4.614 & 4.623 & 48.052 .061 & 50.070 .248 \\
\hline & & Craft & 4.590 & 4.783 & 14.893 & 15.310 & 308.824 .833 & 208.607 .953 \\
\hline \multicolumn{3}{|c|}{ Total } & 17.351 & 17.875 & 64.785 & 65.782 & 2.999.319.346 & 1.499 .659 .673 \\
\hline
\end{tabular}

Source: DIY Bureau of Statistic Center and DIY Industry Office (2017) 
Clearly the table above indexes that Bantul has absorbed mostly the number of labor force in the Special Region of Yogyakarta followed by Gunung Kidul, Kulon Progo, Sleman, dan Yogyakarta. Seen from the point of view of the number of business unit, the table shows that Sleman takes the biggest number and on the other hand, the city of Yogyakarta has the smallest number. It can be concluded that the existence of IKM in each region reflects the opportunity for the disabled to work in that industry.

\section{Compatibility between the Types of Disability and the Types of Creative Industry}

It is important to know that not all of the disable people can work in the IKM in DIY. It is then known among 15 creative industries, the market can only provide the job opportunity in 3 sectors of art goods market, fashion and music industry. The disabled with hearing impairment can get a job at art goods market as crafter; moreover in fashion industry they can work as tailor, and in music industry they can earn income as an advertising maker. The disabled with visual impairment, physical impairment, mental impairment, or both physical and mental impairment can also choose a job which is suitable to their disability condition so far. (Rokhim and Handoyo 2015)

Based on the types of impairment, those with physical followed by hearing impairment can work almost at all sector of industry. Specifically for the physical impairment persons, their disabilities also influence the way they work, for example people with one leg can work better than people without legs. Similar case will also take place for people who lost the function of hand. For the hearing impairment, there is still an opportunity to get a job in the industry which having lessinteract with many other people. (Sayyidah, 2015; Setiadi and Aryanto, 2014)

Exception comes from people with physical and mental impairment. They can only work on certain areas that really match their environment or close to their family. Specifically, there is no evidence of these people working in specific industry.

For mental and both physical and mental impairment disability, they are considered unable to work in some of creative industries. They can work in some less-demanded of complicated procedure or process. Unfortunately, there is still no data referring people with mental impairment working in any types of creative industry.

\section{The Division of the Disable based on the Types of Creative Industry}

Minister of Industry has already divided creative industry into 15 groups consisting of advertising, architecture, art goods

Table 2

Matrix of Types of Creative Industry and Disabled People

\begin{tabular}{|c|c|c|c|c|c|c|}
\hline \multirow[b]{2}{*}{ No } & \multirow[b]{2}{*}{ Types of Creative Industry } & \multicolumn{5}{|c|}{ Types of Disabilities/Impairment } \\
\hline & & Hearing & Visual & Physical & Mental & $\begin{array}{c}\text { Physical } \\
\text { and } \\
\text { Mental }\end{array}$ \\
\hline 1 & Advertising & $\mathrm{V}$ & & $\mathrm{v}$ & & \\
\hline 2 & Architecture & $\mathrm{v}$ & & $\mathrm{v}$ & & \\
\hline 3 & Art goods market & v & v & v & v & v \\
\hline 4 & Craft & $\mathrm{v}$ & & $\mathrm{v}$ & v & v \\
\hline 5 & Design & v & & $\mathrm{v}$ & v & \\
\hline 6 & Fashion & v & v & v & v & v \\
\hline 7 & Video, Film \& Photography & v & & $\mathrm{v}$ & & \\
\hline 8 & Interactive Game & v & v & $\mathrm{v}$ & & \\
\hline 9 & Music & v & v & $\mathrm{v}$ & v & v \\
\hline 10 & Showbiz & v & v & $\mathrm{v}$ & & \\
\hline 11 & Printing and Publishing & v & $\mathrm{v}$ & $\mathrm{v}$ & & \\
\hline 12 & Computer Service \& Software & & $\mathrm{v}$ & v & & \\
\hline 13 & Broadcasting & v & $\mathrm{v}$ & $\mathrm{v}$ & & \\
\hline 14 & Research and Development (R\&D) & v & $\mathrm{v}$ & $\mathrm{v}$ & & \\
\hline 15 & Culinary & $\mathrm{v}$ & & $\mathrm{v}$ & & \\
\hline
\end{tabular}


Table 3

Division of the Disabled Based on the Types of IKM

\begin{tabular}{|c|c|c|c|c|c|}
\hline & Food & $\begin{array}{l}\text { Fashion and } \\
\text { Leather }\end{array}$ & $\begin{array}{l}\text { Chemical and } \\
\text { construction } \\
\text { material }\end{array}$ & $\begin{array}{l}\text { Steel and } \\
\text { Electronics }\end{array}$ & Craft \\
\hline (Advertising) & $\begin{array}{l}\text { Hearing/ } \\
\text { Visual/ Physical } \\
\text { Impairment }\end{array}$ & $\begin{array}{l}\text { Hearing/ } \\
\text { Physical } \\
\text { Impairment } \\
\text { Hearing/ } \\
\text { Physical } \\
\text { Impairment }\end{array}$ & $\begin{array}{l}\text { Hearing/ } \\
\text { Physical } \\
\text { Impairment } \\
\text { Hearing/ } \\
\text { Physical } \\
\text { Impairment }\end{array}$ & & $\begin{array}{l}\text { Hearing/ } \\
\text { Physical } \\
\text { Impairment } \\
\text { Hearing/ } \\
\text { Physical } \\
\text { Impairment }\end{array}$ \\
\hline $\begin{array}{l}\text { Art goods } \\
\text { market }\end{array}$ & $\begin{array}{l}\text { Hearing| Visual| } \\
\text { Physical| } \\
\text { Mental| Physical } \\
\text { and Mental }\end{array}$ & $\begin{array}{l}\text { Hearing| Visual| } \\
\text { Physical| } \\
\text { Mental| Physical } \\
\text { and Mental }\end{array}$ & $\begin{array}{l}\text { Hearing| } \\
\text { Visual| } \\
\text { Physical| } \\
\text { Mental| } \\
\text { Physical and } \\
\text { Mental }\end{array}$ & & $\begin{array}{l}\text { Hearing| Visual| } \\
\text { Physical| } \\
\text { Mental| Physical } \\
\text { and Mental }\end{array}$ \\
\hline $\begin{array}{l}\text { Craft } \\
\text { Design }\end{array}$ & $\begin{array}{l}\text { Hearing| } \\
\text { Physical|Mental| } \\
\text { Physical and } \\
\text { Mental } \\
\text { Hearing| } \\
\text { Physical|Mental }\end{array}$ & $\begin{array}{l}\text { Hearing| } \\
\text { Physical|Mental| } \\
\text { Physical and } \\
\text { Mental } \\
\text { Hearing| } \\
\text { Physical|Mental }\end{array}$ & & $\begin{array}{l}\text { Hearing| } \\
\text { Physical|Mental| } \\
\text { Physical and } \\
\text { Mental }\end{array}$ & $\begin{array}{l}\text { Hearing| } \\
\text { Physical|Mental| } \\
\text { Physical and } \\
\text { Mental } \\
\text { Hearing| } \\
\text { Physical|Mental }\end{array}$ \\
\hline $\begin{array}{l}\text { Fashion } \\
\text { Industry }\end{array}$ & & $\begin{array}{l}\text { Hearing| Visual| } \\
\text { Physical| } \\
\text { Mental| Physical } \\
\text { and Mental }\end{array}$ & & & $\begin{array}{l}\text { Hearing| Visual| } \\
\text { Physical|Mental| } \\
\text { Physical and } \\
\text { Mental }\end{array}$ \\
\hline $\begin{array}{l}\text { Video, } \\
\text { Film and } \\
\text { Photography }\end{array}$ & & $\begin{array}{l}\text { Hearing/ } \\
\text { Physical } \\
\text { Impairment }\end{array}$ & & $\begin{array}{l}\text { Hearing/ } \\
\text { Physical } \\
\text { Impairment }\end{array}$ & $\begin{array}{l}\text { Hearing/ } \\
\text { Physical } \\
\text { Impairment }\end{array}$ \\
\hline $\begin{array}{l}\text { Interactive } \\
\text { Game }\end{array}$ & & & & $\begin{array}{l}\text { Hearing/ } \\
\text { Visual/ Phyical } \\
\text { Impairment }\end{array}$ & $\begin{array}{l}\text { Hearing/ } \\
\text { Visual/ Phyical } \\
\text { Impairment }\end{array}$ \\
\hline Music & & & & $\begin{array}{l}\text { Hearing| } \\
\text { Visual| } \\
\text { Physical| } \\
\text { Mental| } \\
\text { Physical and } \\
\text { Mental }\end{array}$ & $\begin{array}{l}\text { Hearing| Visual| } \\
\text { Physical| } \\
\text { Mental| Physical } \\
\text { and Mental }\end{array}$ \\
\hline Showbiz & $\begin{array}{l}\text { Hearing/ } \\
\text { Visual/ Phyical } \\
\text { Impairment }\end{array}$ & $\begin{array}{l}\text { Hearing/ } \\
\text { Visual/ Phyical } \\
\text { Impairment }\end{array}$ & & $\begin{array}{l}\text { Hearing/ } \\
\text { Visual/ Phyical } \\
\text { Impairment }\end{array}$ & $\begin{array}{l}\text { Hearing/ } \\
\text { Visual/ Phyical } \\
\text { Impairment }\end{array}$ \\
\hline $\begin{array}{l}\text { Printing and } \\
\text { Publishing }\end{array}$ & & & $\begin{array}{l}\text { Hearing/ } \\
\text { Visual/ Phyical } \\
\text { Impairment }\end{array}$ & & $\begin{array}{l}\text { Hearing/ } \\
\text { Visual/ Phyical } \\
\text { Impairment }\end{array}$ \\
\hline $\begin{array}{l}\text { Computer } \\
\text { and Software } \\
\text { Service }\end{array}$ & & & $\begin{array}{l}\text { Visual/ Phyical } \\
\text { Impairment }\end{array}$ & $\begin{array}{l}\text { Visual/ Phyical } \\
\text { Impairment }\end{array}$ & $\begin{array}{l}\text { Visual/ Phyical } \\
\text { Impairment }\end{array}$ \\
\hline Broadcasting & & & & $\begin{array}{l}\text { Hearing/ } \\
\text { Visual/ Phyical } \\
\text { Impairment }\end{array}$ & $\begin{array}{l}\text { Hearing/ } \\
\text { Visual/ Phyical } \\
\text { Impairment }\end{array}$ \\
\hline $\begin{array}{l}\text { Research and } \\
\text { Development } \\
(R \& D)\end{array}$ & $\begin{array}{l}\text { Hearing/ } \\
\text { Visual/ Phyical } \\
\text { Impairment }\end{array}$ & $\begin{array}{l}\text { Hearing/ } \\
\text { Visual/ Phyical } \\
\text { Impairment }\end{array}$ & $\begin{array}{l}\text { Hearing/ } \\
\text { Visual/ Phyical } \\
\text { Impairment }\end{array}$ & $\begin{array}{l}\text { Hearing/ } \\
\text { Visual/ Phyical } \\
\text { Impairment }\end{array}$ & $\begin{array}{l}\text { Hearing/ } \\
\text { Visual/ Phyical } \\
\text { Impairment }\end{array}$ \\
\hline Culinary & $\begin{array}{l}\text { Hearing/ } \\
\text { Physical } \\
\text { Impairment }\end{array}$ & & & & $\begin{array}{l}\text { Hearing/ } \\
\text { Physical } \\
\text { Impairment }\end{array}$ \\
\hline
\end{tabular}


market, craft, design, fashion, video, film and photography, interactive games, music, showbiz, printing and publishing, computer and software service, television and radio, research and development, and culinary. Unfortunately, there is an unavailability of data for the disabled working in these 15 groups, so there is an idea to categorize again these 15 groups into 5 groups of IKM based on the similarity of the data owned by those two types of industry. Table 3 gives clear point of view that these 15 groups are included into 5 small and medium industry, taken for example the industry of advertising which included in the category of food industry, fashion and leather, chemical and construction material, and craft.

Architecture group of industry is still related to the types of chemical and construction material and craft, while goods market is categorized into food industry, fashion and leather, chemical and construction material, and craft as well. Industry of craft, design and showbiz can be included into food industry, fashion and leather industry, chemical and construction material, and craft industry. Games interactive, music and radio industry are the category of steel and electronics and craft. At last, creative industry of research and development can be categorized into all the sectors in IKM.

The positive relationship between creative industry and IKM shows the closeness relationship meaning that one factor can represent the other and vice versa. Unfortunately, not all the creative industry and IKM in general can be utilized by the disabled since they have their own and personal impairment. For example, hearing and physical impairment person have the ability to develop themselves on the food sector such as advertisement, art and goods market, craft, design, showbiz and culinary, research and development.

A craft sector of industry informs that all sectors of creative industry can accommodate the necessity of the disabled to get a job, especially for the hearing impairment which is proven working almost in all sectors of industry except computer and software service. On the other hand, the opportunity to work on the computer and software service are widely open to people with visual and physical impairment. Basically, people with hearing, visual, and physical impairment can get a job at any kinds of small-medium enterprise or industry yet on specific criteria of creative industry.

Weighing based on the types of creative industry related to IKM results on types of food industry which consists of 7 types, fashion industry which consist of 9 types, chemical and construction material which consist of 6 types, steel and electronics which consist of 8 types, and the last types of craft which consist of 15 . The number of the IKM is obtained based on the ratio of the number of creative industry in every sector of IKM. It is then informed that the proportion of disable people working in food industry is $15,56 \%$, fashion and leather are $20,00 \%$, chemical and construction material are $13,33 \%$, steel and electronics are $17,78 \%$ and craft is counted for as many as $33,33 \%$

\section{Opportunity for the Disable People to Work in Creative Industry}

The percentage obtained by each sector of IKM can be used to calculate the proportion of the number of disable people working in it. From the calculation it is known that the highest proportion lies in the craft sector while the lowest calculation is in the chemical and construction material. It shows that the disable people or workers in any types such as visual impairment, hearing impairment, physical impairment, mental impairment, or both physical and mental impairment can get $a$ job in the craft sector. The number of proportion is also influenced by the number of creative industry which included as craft sector. (Effendi, 2017; Macy 1996)

It is then known that the opportunity for the disabled to work in chemical and construction material is smaller, and some of creative industries which can be categorized into chemical and construction material are advertising, art and goods market, printing and publishing, computer and software service, and research and development. It is important to note that the disabled who work in chemical and construction material is only limited to the hearing, visual, and physical impairment since there is a risk to anyone working in this sector, especially for disable people.

In five regions of DIY, it is pictured that the disabled are able to work more in craft industry. On the other hand, the chemical and construction material industry absorb the least number of disable worker. Clearly, Gunungkidul provides more opportunity for the disabled to work compared to other four regions in DIY. On the contrary, Bantul 
Table 4

Job Opportunity in Creative Industry for the Disabled

\begin{tabular}{|c|c|c|c|c|c|c|c|c|}
\hline \multirow[t]{2}{*}{ Region } & \multirow[t]{2}{*}{ Types of Industry } & \multirow[t]{2}{*}{$\begin{array}{l}\text { Proportion } \\
\text { of Industry } \\
\text { Sector Types } \\
\text { for Disable } \\
\text { People }\end{array}$} & \multicolumn{2}{|c|}{$\begin{array}{l}\text { The Number } \\
\text { of Disable } \\
\text { People having } \\
\text { Opportunity } \\
\text { to Work in } \\
\text { Creative } \\
\text { Industry }\end{array}$} & \multicolumn{2}{|c|}{$\begin{array}{l}\text { Opportunity } \\
\text { for the disable } \\
\text { people to Work } \\
\text { in Creative } \\
\text { Industry }\end{array}$} & \multicolumn{2}{|c|}{$\begin{array}{c}\text { Ratio between } \\
\text { Disable People } \\
\text { and Labor } \\
\text { Force }\end{array}$} \\
\hline & & & 2014 & 2015 & 2014 & 2015 & 2014 & 2015 \\
\hline \multirow{5}{*}{ Bantul } & Food & 15,56 & 114 & 295 & 70,93 & 28,10 & 0,43 & 1,07 \\
\hline & Clothing and Leather & 20,00 & 147 & 379 & 5,69 & 2,25 & 2,21 & 5,64 \\
\hline & $\begin{array}{l}\text { Chemical and construction } \\
\text { material }\end{array}$ & 13,33 & 98 & 253 & 30,67 & 12,27 & 0,35 & 0,89 \\
\hline & Steel and electronics & 17,78 & 131 & 337 & 7,68 & 3,07 & 4,52 & 11,62 \\
\hline & Craft & 33,33 & 245 & 632 & 27,98 & 11,30 & 1,03 & 2,55 \\
\hline \multirow{5}{*}{ Gunung Kidul } & Food & 15,56 & 258 & 568 & 35,12 & 16,29 & 0,76 & 1,63 \\
\hline & Clothing and Leather & 20,00 & 295 & 650 & 3,42 & 1,59 & 12,92 & 28,14 \\
\hline & $\begin{array}{l}\text { Chemical and construction } \\
\text { material }\end{array}$ & 13,33 & 221 & 487 & 25,45 & 11,92 & 1,06 & 4,46 \\
\hline & Steel and electronics & 17,78 & 295 & 650 & 3,00 & 1,40 & 7,89 & 17,35 \\
\hline & Craft & 33,33 & 553 & 1.218 & 8,43 & 3,99 & 3,96 & 8,48 \\
\hline \multirow{5}{*}{ Yogyakarta } & Food & 15,56 & 197 & 205 & 10,03 & 9,87 & 2,79 & 2,83 \\
\hline & Clothing and Leather & 20,00 & 225 & 234 & 3,94 & 3,88 & 4,13 & 4,24 \\
\hline & $\begin{array}{l}\text { Chemical and construction } \\
\text { material }\end{array}$ & 13,33 & 169 & 175 & 3,84 & 3,82 & 2,83 & 2,94 \\
\hline & Steel and electronics & 17,78 & 225 & 234 & 2,99 & 2,97 & 10,70 & 11,10 \\
\hline & Craft & 33,33 & 422 & 438 & 2,25 & 2,26 & 6,55 & 6,62 \\
\hline \multirow{5}{*}{ Kulon Progo } & Food & 15,91 & 137 & 175 & 96,90 & 77,75 & 0,37 & 0,46 \\
\hline & Clothing and Leather & 18,19 & 157 & 200 & 6,22 & 5,00 & 4,70 & 5,91 \\
\hline & $\begin{array}{l}\text { Chemical and construction } \\
\text { material }\end{array}$ & 13,64 & 118 & 150 & 8,90 & 7,21 & 3,11 & 3,96 \\
\hline & Steel and electronics & 18,18 & 157 & 200 & 5,44 & 4,41 & 6,34 & 8,06 \\
\hline & Craft & 34,09 & 294 & 374 & 21,71 & 17,76 & 1,55 & 1,92 \\
\hline \multirow{5}{*}{ Sleman } & Food & 15,91 & 236 & 272 & 25,97 & 23,05 & 1,21 & 1,37 \\
\hline & Clothing and Leather & 18,19 & 270 & 311 & 6,46 & 5,73 & 2,94 & 3,34 \\
\hline & $\begin{array}{l}\text { Chemical and construction } \\
\text { material }\end{array}$ & 13,64 & 202 & 233 & 15,15 & 13,57 & 1,22 & 1,40 \\
\hline & Steel and electronics & 18,18 & 270 & 311 & 6,77 & 6,07 & 5,84 & 6,72 \\
\hline & Craft & 34,09 & 506 & 582 & 9,08 & 8,21 & 3,39 & 3,80 \\
\hline
\end{tabular}

Source: DIY Bureau of Statistic Center, DIY Industry Office (2017) and authors (2017)

absorbs the least or minimum number of disabled to get a job in any types of creative industries.

The increase number of disabled in 2015 compared to the last year shows a tendency of decreasing the chance or opportunity for the disabled to get a job in some types of industry. This situation is actually existed in five regions in DIY. Anyhow, the number of possibility for the disabled to get a job is still greater in Bantul and Gunungkidul. In city of Yogyakarta itself, it is noted that the opportunity to get a job for the disabled in
2015 is almost exactly similar to the number of those in 2014.

The ratio between disable people or worker and the labor force in DIY shows that there is a significant increase in the number of disable workers compared to those labor force during 2014-2015. It reflects the condition that many creative industries employ the disable workers in DIY. On the other hand, it is a consequence that the less number of creative industries will cause a decrease number of disable people working in small and medium scale industries. As 
it illustrated in Bantul, Kulonprogo and Sleman, the opportunity to get a job for the disabled in steel and electronics industry is lower than any other industries. Whereas, in Gunungkidul, job opportunity for the disabled to work in the clothing and leather industry is lower than other industries.

Disabled people have a opportunity to compete with the non-disabled in certain creative industry of food, chemical and construction material, and craft since it previously mentioned that such creative industry have an increasing ratio which actually lower compared to any other creative industries. It merely shows that the opportunity for the disabled to get a job is at least equal or similarly equal to the non-disabled, where the creative industry sectoring on food can be an alternative industry for the disable to compete with the able people, especially in the city of Yogyakarta, Kulonprogo and Sleman.

\section{Conclusions}

The first position of the disabled in DIY is taken by those who belong to physical impairment especially in the Gunung Kidul. For people with visual impairment, hearing impairment, mental impairment, both physical and mental impairment are distributed fairly in 4 regions and the city of Yogyakarta itself, even though the number of the disabled is different for each region. It is noted that people with mental impairment are mostly found in Bantul and Sleman. The city of Yogyakarta, on the other hand, shares more variation of disable people compared to other 4 regions in the DIY province. Based on the data of industrial opportunity obtained from Department of Industry and Trade of DIY, there are five main industries which giving prospect in the future for disabled. The industries are food, fashion and leather, chemical and construction material, steel and electronics, and craft. It is observed that food industry took the biggest part of industry among the rest, followed by the craft, chemical and construction material, fashion and leather, and industry of steel and electronics in the last place.

The highest proportion of creative industry is taken by the art sector of industry and on the contrary, the lowest or smallest proportion lies on the industry of chemical and construction material. It means that in the relationship with the disabled people, those who have visual impairment, hearing impairment and others, have greater opportunity to work in the art sector of industry. On the contrary, based on the disability that the disable have, the opportunity to work in the sector of chemical and construction material is lower than other industries. Furthermore, the disabled have the opportunity to compete with nondisabled especially in the industry sector of food, chemical and construction material, and craft since it is known that the rising ratio of these three types of industry sector is lower than any other types of industry. It merely shows that the opportunity for the disabled to get a job is at least equal or similarly equal to other non-disabled, where the creative industry sectoring on food can be an alternative industry for the disable to compete with the able people, especially in the City of Yogyakarta, Kulonprogo and Sleman.

\section{References}

Aji, A.L.D \& Haryani, T.N. (2017). Diversitas dalam Dunia Kerja: Peluang dan Tantangan bagi Disabilitas. Spirit Publik. Vol. 12 (2): 83-93

Booth, A. (2003). Decentralisation and Poverty Alleviation in Indonesia Environment and Planning. Journal of Government and Policy. Vol. 21 (2): 181-202

Dewi, U. (2015). Implementasi Kebijakan Kuota bagi Penyandang Disabilitas untuk Mendapatkan Pekerjaan di Kota Yogyakarta. Natapraja, Jurnal Kajian IImu Administrasi Negara. Vol. 3 (2): 67-83

Effendi, A.B \& Yunianto, R. (2017). Implementasi Diversity Program bagi tenaga Kerja Penyandang Disabilitas pada PT.Wangta Agung Kota Surabaya. Indonesia Journal of Disability Studies. Vol. 4 (2): 96-103

Gustafasson, J., Prieto, J., Peralta \& Danermark, B. (2013). The Employer's Perspective: Employment of People with Disabilities in Wage Subsidized Employments. Scandinavian Journal of Disability Research. Vol. 16 (3): 249-266.

Harahap, R. R. \& Bustanuddin. (2015). Perlindungan Hukum terhadap Penyandang Disabilitas menurut Convention on the Rights of Persons with Disabilities (CRPD), Jurnal Inovatif, Vol. 8(1): 17-29

Heera, S. \& Devi, A. (2016). Employers' Perpective Towards People with Disabilities: A Review of the Literature. The South East Asian Journal of Management. Vol. 10 
(1): $54-74$

Hendriasyah, H. (2013). Wawancara, Observasi, Dan Focus Group: Sebagai Intrumen Penggalian Data Kualitatif, Rajawali Press, Jakarta.

Huang, I. C. \& Chen, R. K. (2015). Employing People With Disabilities in the Taiwanese Workplace Employers' Perceptions and Considerations. Rehabilitation Counseling Bulletin. Vol. 59 (1): 43-54

Hwa, M. A. C. (2012). Rational Tactics and Work Outcomes: Differential Effects of Disability. Internastional Journal of Social Science and Humanity. Vol. 2 (3): 180184

Indrajaya, P. H. (2017). Dream and Poverty Alleviation. Mimbar. Vol. 33 (1): 107-114

Kang, K. (2013). Why Would Companies not Employ People with Disabilities in Korea? Asia Pacific Journal of Social Work and Development. Vol. 23 (3): 222-229

Kaye, H. S., Jans, L. H. \& Jones, E. C. (2011). Why Don't Employers Hire and Retain Workers with Disabilities? Journal of Occupational Rehabilitation. Vol. 21 (4): 526-536.

Latuconsina, Z. (2014). Afirmasi Kebijakan Pemerintah dalam Fasilitasi Kerja bagi Penyandang Disabilitas. Pandecta. Vol. 9 (2): 203-211

Lestari, R. A \& Santoso, E.B (2013). Tipologi Lokasi Industri Kreatif pada Subsektor Kerajinan di Kota Surabaya, Jurnal Teknik Pomits, Vol. 1 (1): 1-4

Lestari, E.Y., Sumarto, S. \& Isdaryanto, N. (2017). Pemenuhan Hak bagi Penyandang Disabilitas di Kabupaten melalui Implementasi Convention on The Rights of Persons with Disabillities (CPRD) dalam Bidang Pendidikan. Integralistik. Vol. 28 (1): 1-9

Macy, G. (1996). Accommodating Employee with Disabilities: A Matter of Attitude. Journal of Managerial Issues. Vol. 8 (1): 78-91.

Maharani, A. E., Isharyanto, P. \& Candrakirana, R. (2014). Pembadanan (Embodying) Kebijakan Berbasis Kapasitas dalam Pemberdayaan Difabel untuk Penanggulangan Kemiskinan", Jurnal Dinamika Hukum. Vol. 14 (1); 83-96.

Masduqi, B. F. (2010). Kecacatan: Dari Tragedi Personal menuju Gerakan Sosial. Jurnal Perempuan, Vol. 65: 17-29.

Mik-Meyer, N. (2016). Disability and Care: Managers, Employees and Colleagues with Impairments Negotiating the Social Order of Disability. Work, Employment and Society. Vol. 30 (6): 984-999.
Moeliono, L. (2012). Focus Group Discussion, Jakarta; Penerbit Universitas Atmajaya.

Moleong, L. (2000). Metode Penelitian Kualitatif, Bandung; Remaja Rosdyakarya.

Naraine, M. D. \& Lindsay, P. H. (2011). Social Inclusion of Employees Who are Blind or Low Vision. Disability \& Society. Vol. 26 (4): 389-403.

Nasution, A., Rustiada. E., Juanda, B. \& Hadi, S. (2014), Dampak Modal Sosial terhadap Kesejahteraan Rumah Tangga Pedesaaan di Indonesia. Mimbar. Vol. 30 (20): 137148.

Nurjanah, S. (2013). Analisis Pengembangan Program Bisnis Industri Kreatif Penerapannya melalui Pendidikan Tinggi. JMA. Vol. 18 (2): 141-151.

Rahayu, S., Dewi, U. \& Ahdiyana, M. (2013). Pelayanan Publik Bidang Transportasi bagi Difabel di Daerah Istimewa Yogyakarta. Socio. Vol. 12 (2): 108-119.

Rizano. (2014). Implementasi Pemenuhan Hak Penyandang Cacat dalam Memperoleh Pekerjaan pada Perusahaan Negara dan Swasta di Kota Pekanbaru Berdasarkan Undang-Undang Nomor 4 Tahun 1997 tentang Penyandang Cacat. Jurnal JOM Fakultas Hukum. Vol. 1 (2): 1-15.

Rokhim, F. \& Handoyo P. (2015). Makna Kerja bagi Penyandang Disabilitas di Yayasan Bina Karya Tiara Handycraft Surabaya. Paradigma. Vol. 3 (3): 1-9.

Rosdianti, Y. (2017). Meaningful Work and Disability: A Dignity Toward Social Inclusion, Indonesia. Journal of Disability Studies (UDS). Vol. 4 (1): 69-86.

Salim, I. (2015). Perspektif Disabilitas dalam Pemilu 2014 dan Kontribusi Gerakan Difabel Indonesia bagi Terbangunnya Pemilu Inklusif di Indonesia. The Politics. Vol. 1 (2): 127-155 .

Santoso, M. B. \& Apsari, N. C. (2017). Pergeseran Paradigma dalam Disabilitas. Intermestic, Journal of International Studies. Vol. 1 (2): 166-176.

Sayyidah, A. N. (2015). Dinamika Penyesuaian Diri Penyandang Disabilitas di Tempat Magang Kerja, Studi Deskriptif di Balai Rehabilitas Terpadu Penyandang Disabilitas (BRTPD) Yogyakarta. Inklusi. Vol. 2 (1):63-86.

Setiadi, N. J \& Aryanto, R. (2014). CreativityRelevant Personal Characateristics Among Indonesia Creative Workers. Journal the Winners. Vol. 15 (2): 140-149.

Surwati, A. (2014). Model Pemberdayaan Ekonomi Penyandang Disabilitas di Indonesia. Jurnal Manajemen dan Bisnis. Vol. 5 (1): 40-58. 